DOI: $10.31933 /$ JIMT

Received: 17 Agustus 2020, Revised: 7 Oktober 2020, Publish: 18 Oktober 2020

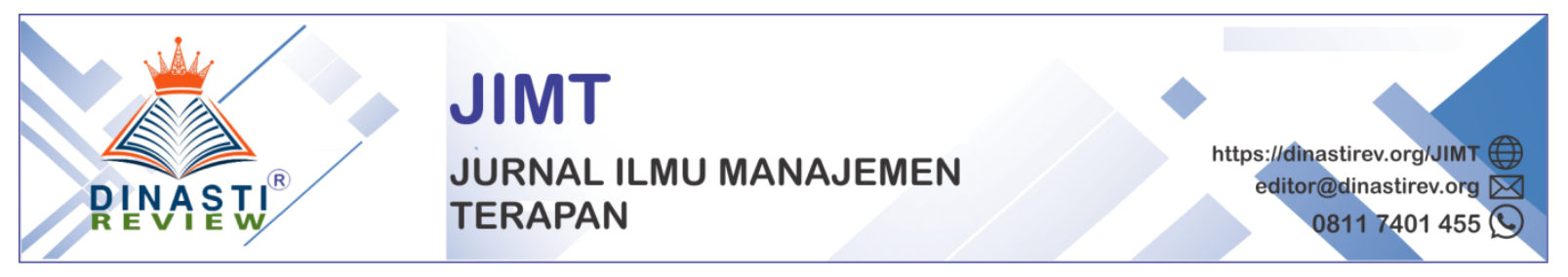

\title{
PERAN PRODUCT KNOWLEDGE TERHADAP PERSEPSI RISIKO MINUMAN KEKINIAN
}

\author{
Hamdan Hamdan ${ }^{1}$, Indra Raharja ${ }^{2}$ \\ 1) Universitas Mercu Buana, Jakarta, Indonesia, hamdan@mercubuana.ac.id \\ 2) Universitas Mercu Buana, Jakarta, Indonesia, indra.raharja2710@gmail.com
}

\begin{abstract}
Abstrak: Penelitian ini tentang peran product knowledge terhadap persepsi risiko psikologi, persepsi risiko fisik dan pengaruhnya terhadap repurchase intention. Desain penelitian ini menggunakan penelitian eksploratif, deskriptif dan kuantitatif. Penentuan sampel penelitian menggunakan Mahasiswa/i Universitas Mercubuana yang pernah mengkonsumsi minuman kekinian dengan teknik purposive sampling yang akan disebar kepada minimal 180 Mahasiswa/i. Temuan ini membuktikan product knowledge memiliki pengaruh positif terhadap persepsi risiko psikologi, product knowledge memiliki pengaruh positif terhadap persepsi risiko fisik, product knowledge berpengaruh positif terhadap repurchase intention, persepsi risiko psikologi berpengaruh negatif terhadap repurchase intention dan persepsi risiko fisik berpengaruh negatif terhadap repurchase intention.
\end{abstract}

Kata kunci: product knowledge, repurchase intention, risiko psikologi, risiko fisik.

\section{PENDAHULUAN}

Popularitas bubble tea yang saat ini disebut sebagai minuman kekinian memiliki peningkatan yang begitu cepat. Dari data GrabFood tahun 2018 peningkatan penjualan minuman mencapai 3.000\% di Asia Tenggara. Posisi Indonesia berada diurutan pertama dengan angka lebih dari 8.500\%. Capaian ini merupakan peningkatan dari Januari sampai dengan Desember 2018 (Astutik, 2019). Respon positif konsumen terhadap minuman kekinian, menimbulkan start-up minuman kekinian membangun model bisnis yang tepat dan efektif dalam menarik pasar potensial. Rekarti et al. (2018) para pelaku usaha perlu menjadikan pesaing sebagai tindakan orientasi, agar tidak kehilangan kompetisi di masa mendatang, yaitu (Woodruff, 1997) dengan menciptakan nilai konsumen merupakan komponen penting yang berkontribusi terhadap keunggulan kompetitif dan (Permana, 2017) kejelasan strategi menjadi penentu utama dalam pengambilan keputusan yang tepat ke depannya.

Walaupun pertumbuhan bisnis minuman kekinian sangat cepat, namun pada kenyataanya masih banyak konsumen yang belum mengetahui efek negatif, jika menkonsumsi berlebihan. Situmorang (2019) minuman bubble tea atau boba memiliki kadar gula yang jauh lebih tinggi dari minuman bersoda. Sedangkan, (Anggraini, 2019) bahwa Dr. Tan Wee Wong menyatakan kandungan gula dalam minuman boba merupakan faktor utama merusak kesehatan. Seperti halnya 
pakar diet Kong Woan Fei menyatakan minuman boba bisa menyebabkan obesitas, karena minuman boba tidak mengandung nutrisi dan tidak memiliki nilai gizi dari minuman tinggi gula.

Aneka topping kerap jadi alternatif pilihan selain boba atau bola tapioka. Topping ini ditambahkan dalam minuman untuk menghasilkan tekstur yang sempurna di mulut. Namun penelitian dari rumah sakit juga menyebutkan bahwa tambahan topping juga akan meningkatkan kalori dan gula dari minuman tersebut. Topping yang paling tinggi kalorinya adalah milk foam (203 kalori) dan cheese foam (180 kalori), sedangkan boba mengandung (156 kalori) (Tim-CNN Indonesia, 2019). Seperti halnya (Nursyabani, 2019) bahwa minuman kekinian, seperti boba, minuman teh, kopi kekinian hingga minuman mangga dikenal sebagai minuman manis kaya gula. Tren pergeseran gaya hidup, menimbulkan minuman kopi atau minuman teh yang dikenal manis akan menawarkan kandungan gula, garam dan penyedap rasa yang lebih sedikit. Bahkan boba dari negara asalnya di Taiwan trennya telah berubah. Mereka bukan lagi mencari flavour atau rasa baru, melainkan gencar dengan minuman dengan bahan-bahan yang lebih menyehatkan. Dengan demikian, (Ali et al., 2016; Limakrisna \& Ali, 2016) jika kinerja produk sesuai dengan harapan, maka akan menciptakan kepuasan konsumen.

Berdasarkan data dan informasi yang telah diuraikan, pentingnya mengkaji tentang pengetahuan produk dan risiko yang dirasakan menyebabkan konsumen bersedia membeli minuman kekinian untuk dikonsumsi. Semakin tumbuh dan berkembangnya peradaban, semakin pentingnya pengetahuan terhadap produk yang dikonsumsi. Tujuan mengonsumsi minuman adalah untuk mendapatkan kesehatan dan kesenangan (Agrawal et al., 2013). Sikap positif konsumen terbentuk saat mereka mengonsumsi produk-produk sehat (Khoiriyah \& Suam Toro, 2014). Timbulnya perilaku pembelian, karena atribut-atribut produk memberikan manfaat dan kesenangan sesuai yang dirasakan (Wang \& Yu, 2016). Pengetahuan tentang produk untuk mengetahui berbagai risiko yang dirasakan akan menentukan sikap atau nilai konsumen, (Kotler \& Keller, 2013) sebab nilai konsumen merupakan bagian dari perilaku pembelian seperti: motif, persepsi, pembelajaran, keyakinan dan sikap.

Penelitian sebelumnya telah banyak mengkaji tentang minat beli ulang diantaranya adalah penelitian yang dikembangkan oleh (Ali, 2019; Firmansyah \& Ali, 2019; Joseph-mathews et al., 2009; Larasetiati \& Ali, 2019; Lin et al., 2011; Pramatatya et al., 2004; Ramdini D.H, 2020; Tasurru \& Salehudin, 2014; Topaloğlu, 2012; Wang \& Yu, 2016). Seperti penelitian (Wang \& Yu, 2016) bahwa pengetahuan terhadap berbagai keunggulan, fungsi, manfaat dan karakteristik produk merupakan komponen-komponen yang membuat konsumen memutuskan untuk membeli kembali, (Sousa et al., 2019) seperti warna, rasa, tekstur, dan kesan keseluruhan. Penelitian yang dikembangkan oleh (Hsu \& Lin, 2006) bahwa rasa dan aroma merupakan atribut yang dinilai konsumen menjadi perhatian lebih atas komposisi yang digunakan. Beneke et al. (2012) bahwa pandangan konsumen terhadap risiko keamanan produk memiliki arti penting terhadap keberlangsungan hidup dan (Angulo \& Gil, 2007) merupakan dampak besar terhadap pembelian pada masa mendatang.

Konsumen dengan pengetahuan yang objektif tentang produk lebih cendrung berpartisipasi untuk melakukan pembelian (Vigar-Ellis et al., 2015) dan dapat meminimumkan risiko yang 
dipersepsikan atas konsekuensi peristiwa yang diterima, seperti risiko fisik risiko (kesehatan) terhadap kekhawatiran seseorang atas kondisi fisiknya akibat mengkonsumsi produk (Wulandari, 2012; Yeung et al., 2010). Sementara itu, (Schiffman \& Kanuk, 2010) mendefinisikan risiko fisik adalah konsekuensi negatif yang dirasakan konsumen dalam memakai suatu produk. Adapun penelitian yang dikembangkan oleh (Lecat et al., 2016) menemukan bahwa harga wajar dan risiko yang dirasakan merupakan faktor utama kesediaan konsumen untuk membeli suatu produk.

Peningkatan minuman kekinian begitu cepat dengan ditandai respon positif konsumen, sehingga membuat para pengusaha membangun model usaha yang tepat dan efektif untuk keberlangsungan bisnis di masa mendatang. Walaupun pertumbuhan minuman kekinian begitu signifikan, ironisnya masih banyak konsumen tidak memiliki pengetahuan cukup tentang minuman tersebut. Diketahui dari berbagai sumber yang relevan topping yang digunakan pada minuman kekinian bisa merusak kesehatan, karena memiliki kandungan gula tinggi. Pengetahuan produk sangat penting bagi konsumen untuk mengurangi risiko terutama risiko fisik, tetapi tidak sedikit konsumen masih mengkonsumsi minuman kekinian untuk mendapat sebuah kesenangan dengan mengabaikan kesahatan. Disebabkan oleh, (Eccles et al., 2013) rangsangan dingin yang dirasakan dalam mulut dianggap sebagai suatu yang menyenangkan ketika haus, dengan kenikmatannya yang memberikan efek menyegarkan.

Berdasarkan fenomena gap tentang minuman kekinian, maka dapat ditentukan rumusan penelitian ini, yaitu: 1) bagaimana product knowledge berpengaruh positif terhadap persepsi risiko psikologi; 2) bagaimana product knowledge berpengaruh positif terhadap persepsi risiko fisik; 3) bagaimana product knowledge berpengaruh positif terhadap repurchase intention; 4) bagaimana persepsi risiko psikologi berpengaruh negatif terhadap repurchase intention; dan 5) bagaimana pengaruh persepsi risiko fisik berpengaruh negatif terhadap repurchase intention.

\section{KAJIAN PUSTAKA}

\section{Brand Knowledge, Risiko Psikologi, Risiko Fisik dan RepurchaseIntention}

Repurchase intention didefinisikan sebagai perilaku seseorang dalam melakukan suatu tindakan tertentu (Schiffman dan Kanuk, 2007). Seperti halnya (Fishbein dan Ajzen, 1975) dalam Theory of Reasoned Action mendefinisikan intensi berperilaku sebagai kecenderungan individu untuk melakukan beberapa perilaku dan (Ajzen, 1991) terbentuknya suatu perilaku tertentu, sebagai rencana yang disengaja untuk membeli produk dalam waktu dekat (Espejel et al., 2008). Adapun (Wang \& Yu, 2016) mendefiniskan repurchase intention mencerminkan perilaku jangka pendek yang diharapkan untuk memprediksi perilaku pembelian aktual konsumen di masa mendatang. Peter dan Olson (2010) dalam penelitiannya menggunakan empat indikator pengetahuan produk, meliputi: atribut produk, manfaat fungsional, manfaat psikologis, dan nilainilai yang diperoleh ketika mengonsumsi suatu produk. Pengetahuan produk memiliki 3 elemen, yaitu: 1) pengetahuan subjektif; 2) pengetahuan objektif; dan 3) pengetahuan berdasarkan pengalaman.

Pentingnya pengetahuan produk baik secara subyektif maupun obyektif bertujuan mengetahui benar atau salah terhadap konsekuensi yang akan diterima (Aertsens et al., 2011; 
Vigar-Ellis et al., 2015), sehingga orang yang memiliki pengetahuan tentang produk cenderung berbagi informasi lebih banyak kepada orang lain (Packard \& Wooten, 2013; Handiman \& Ali, 2019). Pengetahuan produk minuman secara obyektif dipengaruhi oleh pendidikan dan usia dengan konsumen yang lebih tua dan lebih berpendidikan memiliki pengetahuan, karena memiliki pengetahuan yang lebih objektif terhadap perilaku pembelian (Forbes et al., 2008; Robson et al., 2014). Atribut produk memiliki pengaruh penting bagi konsumen ketika pengetahuan subjektif menjadi dasar pengambilan keputusan (Vigar-Ellis et al., 2015). Pengetahuan produk berperan menghindari konsekuensi negatif terhadap produk yang akan dikonsumsi (Aertsens et al., 2011; Barber et al., 2009; Lacey et al., 2009), yang akan menimbulkan repurchase intention konsumen (Barber et al., 2013).

Pentingnya pengetahuan terhadap kandungan produk yang akan dikonsumsi (Roseman et al., 2017), agar terhindar dari konsekuensi negatif (Ganther \& Kreling, 2000; Goudeau, 2014; Shim \& You, 2015; Yoo \& Kim, 2012). Semakin tumbuh dan berkembangnya peradaban, semakin pentingnya pengetahuan terhadap produk yang dikonsumsi (Agrawal et al., 2013). Gaya hidup sehat perlu dianjurkan untuk membuat sikap konsumen terhadap makanan lebih positif (Danelon \& Salay, 2012; Goudeau, 2014). Dengan informasi berbagi atribut produk yang dijamin kesehatannya akan meningkatkan persepsi positif konsumen (Liana et al., 2010).

Model penelitian yang dikembangkan (Vigar-Ellis et al., 2015; Yeung et al., 2010) bahwa pengetahuan tentang berbagai atribut produk merupakan strategi mengurangi risiko atas kemudahan pembelian. Pengetahuan tantang atribut-atribut yang melekat pada produk akan mempengaruhi pembelian kembali di masa mendatang (Qing et al., 2012; Wang \& Yu, 2016; Yeung et al., 2010). Selain itu, (Barber et al., 2008) menemukan bahwa pengetahuan subyektif lebih erat terkait dengan pengalaman dan konsumsi minuman masa lalu daripada pengetahuan minuman yang sebenarnya. Pengetahuan subyektif telah terkait erat dengan pengambilan keputusan (Dodd et al., 2005), dalam pemasaran produk hijau (Barber et al., 2009) dan dalam kasus sayuran organik (Aertsens et al., 2011) telah ditemukan menjadi prediktor yang lebih baik dalam perilaku pembelian. Dari hasil review penelitian sebelumnya, peneliti mengajukan hipotesis, bahwa:

H1 : Product knowledge berpengaruh positif terhadap persepsi risiko psikologi.

H2 : Product knowledge berpengaruh positif terhadap persepsi risiko fisik.

H3 : Product knowledge berpengaruh positif terhadap persepsi repurchase intention.

\section{Risiko Psikologi, Risiko Fisik dan Repurchase Intention}

Peter dan Olson (2010) mendefinisikan persepsi risiko sebagai konsekuensi negatif yang dihindari konsumen saat mengonsumsi suatu produk. Sementara itu, Schiffman dan Kanuk (2010) menjelaskan persepsi risiko merupakan ketidakpastian yang tidak dapat diprediksi akibatnya ketika konsumen malakukan keputusan pembelian. Persepsi risiko terbentuk dibangun melalui aspek risiko psikologi, aspek risiko keuangan, aspek risiko kinerja aspek risiko fisik dan aspek risiko sosial.

Tujuan konsumen untuk mengkonsumsi minuman adalah untuk mendapatkan kesenangan (Agrawal et al., 2013; Eccles et al., 2013). Perilaku pembelian konsumen dapat dipengaruhi oleh 
kehawatirannya terhadap produk yang akan dibeli (Bruwer et al., 2013; Lacey et al., 2009). Potensi risiko mempengaruhi perilaku pembelian (Bhukya \& Singh, 2015; Goudeau, 2014; Khoiriyah \& Suam Toro, 2014; Yoo \& Kim, 2012), disebabkan risiko yang dipersepsikan negatif akan mengurangi keinginan konsumen untuk melakukan pembelian kembali (Danelon \& Salay, 2012; Hasan, 2017; Shim \& You, 2015). Risiko yang paling dominan mempengaruhi konsumen dalam repurchase intention adalah risiko psikologi (Bruwer et al., 2013; Liana et al., 2010). Seperti halnya, model penelitian (Wang, 2015; Wang \& Yu, 2016) bahwa persepsi risiko psikologi yang dirasakan memiliki pengaruh besar terhadap niat untuk melakukan pembelian ulang. Respons emosional mewakili risiko psikologi yang terkait dengan konsumsi produk atau layanan (Park, 2004). Rangsangan dingin yang dirasakan dalam mulut dianggap sebagai suatu yang menyenangkan ketika haus, dengan kenikmatannya yang memberikan efek menyegarkan (Eccles et al., 2013). Temuan oleh (Beneke et al., 2013; Yoo \& Kim, 2012) bahwa terdapat pengaruh ne negatif antara persepsi risiko psikologi dengan repurchase intention.

Risiko fisik merupakan risiko kesehatan dan keamanan (Beneke et al., 2012; Bruwer et al., 2013). Kekhawatiran konsumen terhadap kondisi fisiknya akibat dari menggunakan suatu produk (Wulandari, 2012; Yeung et al., 2010), karena kurangnya pengetahuan terhadap produk tersebut (Lecat et al., 2016; Min et al., 2016). Ketakutan akan produk telah meningkatkan kekhawatiran, terutama keamanan akan produk yang dikonsumsi (Angulo \& Gil, 2007; Yeung et al., 2010), ada baiknya mengetahui informasi dari berbagai atribut produk sebelum melakukan pembelian (Dodd et al., 2005; Ganther \& Kreling, 2000; Packard \& Wooten, 2013). Informasi tentang produk memiliki peran penting dalam mendorong gaya hidup sehat, karena konsumen menginginkan pilihan menu yang lebih sehat (Roseman et al., 2017). Temuan (Beneke et al., 2013; Yoo \& Kim, 2012) bahwa tidak ada pengaruh signifikan antara persepsi risiko dengan repurchase intention. Dari hasil review penelitian sebelumnya, peneliti mengajukan hipotesis, bahwa:

$\mathrm{H} 4$ : Persepsi risiko psikologi berpengaruh negatif terhadap repurchase intention.

H5 : Persepsi risiko fisik berpengaruh negatif terhadap repurchase intention.

\section{METODE PENELITIAN}

Jenis penelitian ini adalah deskriptif-kuantitatif. Penelitian deskriptif-kuantitatif bertujuan menggambarkan karakteristik suatu fenomena dan merupakan cara terbaik menyelesaikan persoalan dan membuktikan hipotesis (Shields \& Rangarajan, 2013; Shuttleworth, 2008). Dengan menekankan pengukuran objektif dan analisis statistik yang dikumpulkan melalui kuesioner dalam menjelaskan fenomena tersebut (Babbie, 2010). Populasi penelitian adalah Mahasiswa/i Universitas Mercu Buana, karena telah mengetahui tentang minuman kekinian, dimana penentuan sampel menggunakan teknik pursposive sampling, yaitu pemilihan responden sesuai pemahaman dalam mendefinisikan fenomena tertentu (Robinson, 2014). Kriteria responden penelitian adalah yang pernah mengkonsumsi minuman kekinian.

Teknik analisis data penelitian ini menggunakan SEM-Covarian dengan softwere LISREL. Dalam SEM terdapat 3 evaluasi sebagai tingkat kecocokan data dengan model yang dikembangkan (Hair et al. 2010), yaitu: a) kecocokan keseluruhan model dievaluasi melalui GOF dengan 
pengujian: absolute fit model, incremental fit model, dan parsimonious fit model; b) kecocokan model pengukuran dievaluasi dengan uji validitas, uji reliabiltas dan uji varian, asumsinya adalah jika indikator dengan factor loading $(\lambda \geq 0.70)$ dinyatakan valid dan sebaliknya, sedangkan uji reliabilitas yang baik, jika nilai construct reliability $(\mathrm{CR} \geq 0.70)$ dan nilai average variance (VE $\geq 0.50$ ); c) kecocokan model struktural dievaluasi melalui pengujian hubungan antarvariabel dengan asumsi jika t-statisti $>1.96(\alpha=5 \%)$ dinyatakan signifikan serta apakah koefisien hubungan antar variabel positif atau negatif.

\section{HASIL DAN PEMBAHASAN}

\section{Hasil}

Untuk mengevaluasi model penelitian yang dibangun sesuai model yang telah dibentuk diperlukan beberapa cara untuk mendapatkan hasil pada tingkat kriteria uji baik. Penelitian yang dibangun bertujuan untuk menjawab apakah variabel-variabel yang diteliti yaitu: product knowledge, persepsi risiko psikologi, persepsi risiko fisik dan minat beli ulang memiliki tingkat uji baik.

Kecocokan Keseluruhan Model. Uji kecocokan keseluruhan model bertujuan untuk melihat sebarapa baik antara data dengan model (GOF). Uji yang digunakan untuk mencapai GOF dievaluasi melalui uji absolute fit model, uji absolute fit model, dan uji parsimonious fit model. Hasil nilai pengukuran absolute fit model, yaitu: RMSEA $=0.079 \leq 0.08$ (good fit), $\mathrm{GFI}=0.86 \geq 0.90$ (marginal fit), dan $\mathrm{RMR}=0.082 \leq 0.05$ (marginal fit). Hasil pengukuran incremental fit model, yaitu: $\mathrm{CFI}=0.94 \geq 0.90$ (good fit); $\mathrm{NFI}=0.90 \geq 0.90$ (good fit); $\mathrm{NNFI}=0.93 \geq 0.90($ good fit $) ; \mathrm{IFI}=0.94 \geq 0.90($ good fit $) ;$ dan RFI $=0.87 \leq 0.90($ marginal fit $)$. Hasil pengukuran parsimonious fit model, yaitu: $\mathrm{AGFI}=0.81 \leq 0.90$ (marginal fit) dan $\mathrm{PGFI}=0.62 \geq 0.50$ (marginal fit). Terdapat hasil kecocokan keseluruhan model yang belum memenuhi kriteria GOF, seperti GFI, RMR, RFI, AGFI dan PGFI. Walaupun demikian, model tetap dikatakan baik karena nilai RMSEA berada pada tingkat kriteria uji baik atau Good of Fit (GOF).

Kecocokan Model Pengukuran. Dalam penelitian ini data primer yang terkumpul dan layak untuk diolah adalah 187 sampel, karena telah memenuhi asumsi penentuan sampel. Pengukuran yang digunakan untuk mengeliminasi item-item yang tidak valid adalah pengukuran Confirmatory Factor Analysis dengan kaidah Maximum Likelihood. Hasil pengujian konstruk validitas, reliabilitas dan rata-rata variasi untuk masing-masing pengaruh indikator terhadap variabel latennya dapat diuraikan sebagai berikut:

a. Konstruk laten product knowledge meliputi: mengerti tentang minuman kekinian ( $\lambda=0.84$; $\varepsilon=0.30)$, tahu menilai kualitas minuman kekinian $(\lambda=0.82 ; \varepsilon=0.32)$, banyak mengetahui minuman kekinian $(\lambda=0.83 ; \varepsilon=0.31)$ dan penggunaan topping $(\lambda=0.60 ; \varepsilon=0.64)$. Berdasarkan pengujian konstruk validitas dapat ditentukan perhitungan $\mathrm{CR}=0.858 \geq 0.70$ dan $\mathrm{VE}=0.607 \geq 0.50$.

b. Konstruk laten persepsi risiko psikologi meliputi: merasa tidak bahagia $(\lambda=0.86 ; \varepsilon=0.26)$, rasa dan kesegaran tidak nikmat $(\lambda=0.83 ; \varepsilon=0.31)$, tidak membuat santai $(\lambda=0.85 ; \varepsilon=0.27)$ 
tidak meningkatkan citra diri $(\lambda=0.64 ; \varepsilon=0.59)$. Berdasarkan pengujian konstruk validitas dapat ditentukan perhitungan $\mathrm{CR}=0.876 \geq 0.70$ dan $\mathrm{VE}=0.641 \geq 0.50$.

c. Konstruk laten persepsi risiko fisik meliputi: khawatir kadar gula tinggi $(\lambda=0.85 ; \varepsilon=0.27)$, khawatir tidak aman $(\lambda=0.97 ; \varepsilon=0.07)$, khawatir merusak kesehatan $(\lambda=1.01 ; \varepsilon=-0.01)$ dan khawatir membahanyakan fisik $(\lambda=0.86 ; \varepsilon=0.26)$. Berdasarkan pengujian konstruk validitas dapat ditentukan perhitungan $\mathrm{CR}=0.957 \geq 0.70$ dan $\mathrm{VE}=0.849 \geq 0.50$.

d. Konstruk laten minat beli ulang meliputi: kemungkinan membeli kembali $(\lambda=0.70 ; \varepsilon=0.52)$, dan berniat mencoba rasa baru $(\lambda=0.79 ; \varepsilon=0.38)$. Berdasarkan pengujian konstruk validitas dapat ditentukan perhitungan $\mathrm{CR}=0.711 \geq 0.70$ dan $\mathrm{VE}=0.553 \geq 0.50$.

Dengan demikian, konstruk laten product knowledge, persepsi risiko psikologi, persepsi risiko fisik, dan minat beli ulang telah memenuhi kriteria uji baik pada tingkat uji baik, karena semua item-item valid dan konsisten serta memiliki keberagaman dalam mengukur variabel latennya.

Kecocokan Model Struktural. Kecocokan model struktural bertujuan untuk memastikan hubungan antarvariabel yang telah dibangun dengan melihat nilai koefisien dan nilai tstatistiknya. Hasil dari model konseptual yang dibangun ditunjukkan pada Gambar 2 di bawah ini.

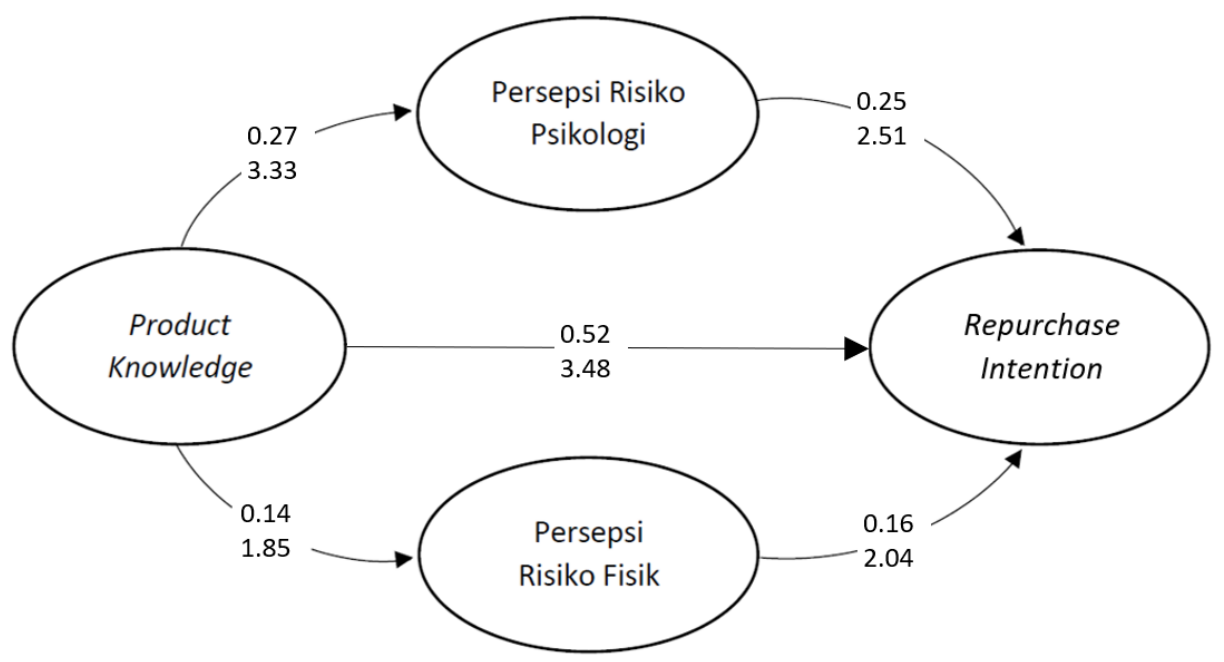

Gambar 1. Hasil Model Struktural

\section{Pembahasan}

Hasil kecocokan model struktural yang dibangun adalah untuk menjelaskan peran product knowledge terhadap persepsi risiko minuman kekinian. Hubungan antarvariabel yang dibangun adalah: 1) pengaruh positif antara product knowledge dengan persepsi risiko psikologi; 2) pengaruh positif antara product knowledge dengan persepsi risiko fisik; 3) pengaruh positif antara product knowledge dengan repurchase intention; 4) pengaruh negatif antara persepsi risiko psikologi dengan repurchase intention; dan 5) pengaruh negatif antara persepsi risiko fisik dengan repurchase intention. 
Product knowledge berpengaruh positif terhadap persepsi risiko psikologi. Hasil penelitian antara product knowledge terhadap persepsi risiko psikologi diperoleh nilai koefisien adalah 0.27 dan t-statistik di atas 1.96. Dimana, koefisien nilai product knowledge dalam mempengaruhi persepsi risiko psikologi adalah positif dan nilai t-statistiknya adalah signifikan. Artinya, product knowledge berpengaruh positif signifikan terhadap persepsi risiko psikologi. Berdasarkan hipotesis yang telah dibangun yaitu product knowledge memiliki pengaruh positif terhadap persepsi risiko psikologi $(+\mathrm{H} 1)$ dapat diterima, karena nilai koefisian yang diperoleh memiliki tingkat kriteria pada tingkat uji baik. Dengan demikian, semakin konsumen memiliki banyak informasi, pengetahuan dan pengalaman tentang minuman kekinian, akan mengurangi risiko psikologi yang dirasakan, artinya konsumen akan merasa bahagia, santai dan meningkatkan citra diri ketika mengonsumsi minumak kekinian. Penelitian yang dikembangan sesuai dengan penelitian yang dikembangkan oleh (Aertsens et al., 2011; Vigar-Ellis et al., 2015; Packard \& Wooten, 2013; Handiman \& Ali, 2019) bahwa pengetahuan produk memiliki pengaruh positif terhadap persepsi risiko psikologi.

Product knowledge berpengaruh positif terhadap persepsi risiko fisik. Hasil penelitian antara product knowledge terhadap persepsi risiko fisik diperoleh nilai koefisien adalah 0.14 dan $\mathrm{t}$-statistik di atas 1.85. Dimana, koefisien nilai product knowledge dalam mempengaruhi persepsi risiko fisik adalah positif dan nilai t-statistiknya tidak signifikan. Artinya, product knowledge berpengaruh positif, tetapi tidak signifikan terhadap persepsi risiko fisik. Berdasarkan hipotesis yang telah dibangun yaitu product knowledge memiliki pengaruh positif terhadap persepsi risiko fisik $(+\mathrm{H} 2)$ dapat diterima, karena nilai koefisian yang diperoleh memiliki tingkat kriteria pada tingkat uji baik. Dengan demikian, semakin konsumen memiliki banyak pengetahuan dari berbagai informasi yang diperoleh dan telah memiliki pengalaman tentang minuman kekinian, akan semakin mengurangi risiko fisik yang dirasakan, artinya konsekuensi terhadap fisik konsumen akibat mengonsumsi minuman kekinian semakin rendah. Temuan ini sesuai dengan (Roseman et al., 2017; Ganther \& Kreling, 2000; Goudeau, 2014; Shim \& You, 2015; Yoo \& Kim, 2012) bahwa pengetahuan produk memiliki pengaruh positif terhadap persepsi risiko fisik.

Product knowledge berpengaruh positif terhadap repurchase intention. Hasil penelitian menunjukkan pengaruh product knowledge terhadap repurchase intention diperoleh nilai koefisien adalah 0.52 dan t-statistik di atas 3.48. Dimana, koefisien nilai product knowledge dalam mempengaruhi repurchase intention adalah positif dan nilai t-statistiknya adalah signifikan. Artinya, product knowledge berpengaruh positif signifikan terhadap repurchase intention. Berdasarkan hipotesis yang dibangun dalam penelitian ini adalah product knowledge berpengaruh positif terhadap repurchase intention $(+\mathrm{H} 3)$ dapat diterima, karena nilai koefisian yang diperoleh memiliki tingkat kriteria pada tingkat uji baik. Dengan demikian, semakin banyak informasi, pengetahuan dan pengalaman yang diperoleh konsumen, semakin meningkat pula pembelian Kembali terhadap minuman kekinian. Temuan ini sesuai dengan (Aertsens et al., 2011; Qing et al., 2012; Wang \& Yu, 2016; Yeung et al., 2010) bahwa pengetahuan produk memiliki pengaruh positif terhadap repurchase intention. 
Persepsi risiko psikologi berpengaruh negatif terhadap repurchase intention. Hasil penelitian, yaitu pengaruh persepsi risiko psikologi terhadap repurchase intention diperoleh nilai koefisien adalah 0.25 dan t-statistik di atas 2.51. Dimana, koefisien nilai persepsi risiko psikologi dalam mempengaruhi repurchase intention adalah positif dan nilai t-statistiknya adalah signifikan. Artinya, persepsi risiko psikologi berpengaruh positif signifikan terhadap repurchase intention. Berdasarkan hipotesis yang telah dibangun yaitu persepsi risiko psikologi memiliki pengaruh negatif terhadap repurchase intention (-H4) tidak dapat diterima, karena nilai koefisian yang diperoleh adalah positif. Hal ini berarti, risko psikologi yang dirasakan konsumen dapat mengurangi pembelian kembali, diamana menurunya pembelian kembali konsumen disebabkan minuman kekinian sudah tidak lagi dijadikan sebagai hal baru/gaya hidup. Temuan ini berbeda dengan penelitian yang dikembangkan oleh (Agrawal et al., 2013; Eccles et al., 2013; Wang, 2015; Wang \& Yu, 2016) menemukan adanya pengaruh negatif antara risiko psikologi dengan repurchase intention.

Persepsi risiko fisik berpengaruh negatif terhadap repurchase intention. Hasil penelitian, yaitu pengaruh persepsi risiko fisik terhadap repurchase intention diperoleh nilai koefisien adalah 0.25 dan t-statistik di atas 2.51. Dimana, koefisien nilai persepsi risiko fisik dalam mempengaruhi repurchase intention adalah positif dan nilai t-statistiknya adalah signifikan. Artinya, persepsi risiko fisik berpengaruh positif signifikan terhadap repurchase intention. Berdasarkan hipotesis yang dibangun yaitu persepsi risiko fisik berpengaruh negatif terhadap repurchase intention (H5) tidak dapat diterima, karena nilai koefisian yang diperoleh adalah positif. Hal ini berarti, risiko fisik yang dirasakan konsumen membentuk perilaku pembelian terhadap minuman kekinian, karena menganggap menuman kekinian tidak terlalu berdampak terhadap kondisi fisik. Hasil penelitian ini berbeda dengan temuan oleh (Beneke et al., 2012; Kelley et al., 2015; Lecat et al., 2016; Min et al., 2016) bahwa persepsi risiko fisik memiliki pengaruh negatif terhadap repurchase intention.

\section{KESIMPULAN DAN SARAN}

\section{Kesimpulan}

Penelitian yang dibangun bertujuan untuk menjawab hipotesis yang dibangun sesuai rumusan penelitian. Penelitian ini tentang peran product knowledge terhadap persepsi risiko minuman kekinian. Dimana perilaku konsumen ketika melakukan pembelian ulang apakah dipengaruhi oleh pengetahuan produk, persepsi risiko psikologi dan persepsi risiko fisik. Temuan penelitian ini meliputi: 1) product knowledge berpengaruh positif terhadap persepsi risiko psikologi, artinya risiko psikologi yang dipersepsikan konsumen dapat diterima, karena konsumen tahu tentang berbagai macam atau varian rasa minuman kekinian; 2) product knowledge berpengaruh positif terhadap persepsi risiko fisik, artinya pengetahuan yang dimiliki konsumen berdasarkan informasi yang diperoleh tentang minuman kekinian yang akan dikonsumsinya memiliki konsekwensi fisik atau kesehatan; 3) product knowledge berpengaruh positif terhadap repurchase intention, artinya semakin tinggi pengetahuan konsumen terhadap minumakan kekinian akan meningkatkan pula perilaku pembelian ulang konsumen; 4) persepsi 
risiko psikologi berpengaruh negatif terhadap repurchase intention, artinya risiko psikologi yang dipersepsikan konsumen saat mengkonsumsi minuman kekinian menimbulkan keinginan untuk membeli ulang; dan 5) persepsi risiko fisik berpengaruh negatif terhadap repurchase intention, artinya konsumen cendrung melakukan pembelian kembali minuman kekinian, karena mengetahui konsekwensi yang diterima melebihi harapan.

\section{Saran}

Penelitian ini menyarankan untuk bidang akademisi dengan memberikan pengetahuan bahwa kecendrungan konsumen melakukan pembelian ulang, dikarenakan adanya faktor yang mempengaruhi seperti pengetahuan produk, persepsi risiko psikologi dan persepsi risiko fisik. Adapun kekurangan penelitian ini, yaitu populasi dan sampel yang digunakan masih sedikit, sehingga perlu ditambahkan sampel penelitian yang lebih banyak. Kekurangan lainnya adalah lebih mengkaji faktor-faktor dominan seperti persepsi risiko fisik, dan faktor lainnya adalah kesadaran merek, pengetahuan produk, label dan komposisi produk

Sedangkan rekomendasi manajerial berdasarkan temuan penelitian ini adalah mengimplementasikan aspek-aspek yang mempengaruhi perilaku pembelian konsumen meliputi: kualitas minuman kekinian, memperbanyak varian ras baru, modifikasi dengan buah-buahan, diversivikasi produk. Dimana aspek-aspek tersebut dapat membentuk sikap dan perilaku positif konsumen untuk melakukan pembelian ulang yang dibangun melalui aspek kemungkinan membeli kembali dan berniat untuk membeli ulang dalam waktu dekat. Implementasi faktor-faktor tersebut bagi para pelaku usaha merupakan pertimbanagn penting, karena ketepatan strategi pemasaran menjadi penentu utama dalam keunggulan dan keberlangsungan bisnis di masa mendatang.

\section{DAFTAR RUJUKAN}

Aertsens, J., Mondelaers, K., Verbeke, W., \& Buysse, J. (2011). The influence of subjective and objective knowledge on attitude, motivations and consumption of organic food. https://doi.org/10.1108/00070701111179988

Agrawal, G. K., Timperio, A. M., Zolla, L., Bansal, V., Shukla, R., \& Rakwal, R. (2013). Biomarker discovery and applications for foods and beverages: Proteomics to $\begin{array}{llll}\text { nanoproteomics. Journal of Proteomics, } & \text { 93, }\end{array}$ https://doi.org/10.1016/j.jprot.2013.04.014

Ali, H. (2019). Building Repurchase Intention and Purchase Decision: Brand Awareness and Brand Loyalty Analysis (Case Study Private Label Product in Alfamidi Tangerang). Saudi Journal of Humanities and Social Sciences, 04(09), 623-634. https://doi.org/10.36348/sjhss.2019.v04i09.009

Ali, H., Limakrisna, N., \& Jamaluddin, S. (2016). Model of customer satisfaction: The empirical study at Bri in Jambi. International Journal of Applied Business and Economic Research, 14(6), 3527-3534.

Angulo, A. M., \& Gil, J. M. (2007). Risk perception and consumer willingness to pay for certified beef in Spain. Food Quality and Preference, 18(8), 1106-1117. https://doi.org/10.1016/j.foodqual.2007.05.008

Babbie, E.R. (2010). The Practice of Social Research. London: Cengage Learning.

Barber, N. A., Taylor, D. C., Barber, N. A., \& Taylor, D. C. (2013). Experimental approach to 
assessing actual wine purchase behavior. https://doi.org/10.1108/IJWBR-2012-0013

Barber, N., Dodd, T., \& Ghiselli, R. (2008). Capturing the younger wine consumer. Journal of Wine Research, 19(2), 123-141. https://doi.org/10.1080/09571260802622225

Barber, N., Taylor, C., \& Strick, S. (2009). Wine consumers' environmental knowledge and attitudes: Influence on willingness to purchase. International Journal of Wine Research, 1(1), 59-72. https://doi.org/10.2147/IJWR.S4649

Beneke, J., Flynn, R., Greig, T., Mukaiwa, M., Beneke, J., Flynn, R., Greig, T., \& Mukaiwa, M. (2013). private label merchandise The influence of perceived product quality, relative price and risk on customer value and willingness to buy: a study of private label merchandise. https://doi.org/10.1108/JPBM-02-2013-0262

Beneke, J., Greene, A., Lok, I., \& Mallett, K. (2012). The influence of perceived risk on purchase intent - the case of premium grocery private label brands in South Africa. Journal of Product \& Brand Management, 21(1), 4-14. https://doi.org/10.1108/10610421211203060

Bhukya, R., \& Singh, S. (2015). The effect of perceived risk dimensions on purchase intention: An empirical evidence from Indian private labels market. American Journal of Business, 30(4), 218-230. https://doi.org/10.1108/AJB-10-2014-0055

Bruwer, J., Fong, M., Saliba, A., Bruwer, J., \& Fong, M. (2013). Perceived risk, risk-reduction strategies ( RRS ) and consumption occasions Roles in the wine consumer's purchase decision. https://doi.org/10.1108/APJML-06-2012-0048

Danelon, M. S., \& Salay, E. (2012). Perceived physical risk and risk-reducing strategies in the consumption of raw vegetable salads in restaurants. Food Control, 28(2), 412-419. https://doi.org/10.1016/j.foodcont.2012.05.026

Dodd, T. H., Laverie, D. A., Wilcox, J. F., \& Duhan, D. F. (2005). Differential Effects of Experience, Subjective Knowledge, and Objective Knowledge on Sources of Information used in Consumer Wine Purchasing. Journal of Hospitality and Tourism Research, 29(1), 319. https://doi.org/10.1177/1096348004267518

Eccles, R., Du-Plessis, L., Dommels, Y., \& Wilkinson, J. E. (2013). Cold pleasure. Why we like ice drinks, ice-lollies and ice cream. Appetite, 71, 357-360. https://doi.org/10.1016/j.appet.2013.09.011

Firmansyah, N., \& Ali, H. (2019). Consumer Trust Model : The Impact of Satisfaction and EService Quality toward Repurchase Intention in E-Commerce. 6256, 552-559. https://doi.org/10.21276/sjhss.2019.4.8.4

Forbes, S., Cohen, D., \& Dean, D. (2008). International Conference of the Academy of Wine Business Research, Siena, 17-19 July, 2008. 4-5.

Ganther, J. M., \& Kreling, D. H. (2000). Consumer Perceptions of Risk and Required Cost Savings for Generic Prescription Drugs. Journal of the American Pharmaceutical Association, 40(3), 378-383. https://doi.org/10.1016/S1086-5802(16)31086-5

Goudeau, H. L. C. (2014). Consumers ' beliefs, attitudes, and loyalty in purchasing organic foods The standard learning hierarchy approach. https://doi.org/10.1108/BFJ-02-2013-0030

Hair, J. F., Black, W. C., Babin, B. J., \& Anderson, R. E. (2010), Multivariate Data Analysis: A Global Perspective. 7the edn. Englewood Cliffs, NJ: Prentice-Hall.

Hasan, G. (2017). Pengaruh faktor resiko terhadap purchase intention private label brand terhadap masyarakat Batam. Journal of Accounting \& Management Innovation, 1(1).

Islam, M. S., Islam, M. S., \& Hasan, M. M. (2009). Development Model of Marketing Capabilities and Export Performance of SMEs: A Proposed Study. European Journal of Business and Management, 10(22), 107-114. https://doi.org/10.13140/ejbm.2013.55.65 
Joseph-mathews, S., Bonn, M. A., \& Snepenger, D. (2009). Atmospherics and consumers' symbolic interpretations of hedonic services. International Journal of Culture, Tourism and Hospitality Research, 3(3), 193-210. https://doi.org/10.1108/17506180910980519

Kelley, K., Hyde, J., Bruwer, J., Kelley, K., \& Hyde, J. (2015). U. S . wine consumer preferences for bottle characteristics, back label extrinsic cues and wine composition. https://doi.org/10.1108/APJML-09-2014-0140

Khoiriyah, S., \& Suam Toro, M. J. (2014). Faktor-Faktor Yang Mempengaruhi Kesediaan Membeli Produk Hijau. Jurnal Bisnis \& Manajemen, 1(1), 63-76.

Kinerja, T., Pada, K., Trans, P. T., \& Indonesia, R. (2016). Jurnal Mirai Management, . 1(2), 211227.

Lacey, S., Bruwer, J., Li, E., Lacey, S., Bruwer, J., \& Li, E. (2009). The role of perceived risk in wine purchase decisions in restaurants. https://doi.org/10.1108/17511060910967962

Larasetiati, M., \& Ali, H. (2019). Model of Consumer Trust: Analysis of Perceived Usefulness and toward Repurchase Intention in Online Travel Agent. Journal of Economics and Finance, 3(8), 350-357. https://doi.org/10.21276/sjef.2019.3.8.5

Lecat, B., Le Fur, E., \& Outreville, J. F. (2016). Perceived risk and the willingness to buy and pay for "corked" bottles of wine. International Journal of Wine Business Research, 28(4), 286307. https://doi.org/10.1108/IJWBR-08-2015-0031

Liana, M., Radam, A., \& Yacob, M. R. (2010). Consumer Perception Towards Meat Safety: Confirmatory Factor Analysis. 4(2), 305-318.

Limakrisna, N., \& Ali, H. (2016). Model of Customer Satisfaction: Empirical Study At Fast Food Restaurants in Bandung. International Journal of Business and Commerce, 5(06), 132-146. www.ijbcnet.com

Lin, H. H., Wang, Y. S., \& Chang, L. K. (2011). Consumer responses to online retailer's service recovery after a service failure: A perspective of justice theory. Managing Service Quality, 21(5), 511-534. https://doi.org/10.1108/09604521111159807

Min, J. E., Green, D. B., \& Kim, L. (2016). Calories and sugars in boba milk tea : implications for obesity risk in Asian Pacific Islanders. Townsend 2014, 1-8. https://doi.org/10.1002/fsn3.362

Packard, G., \& Wooten, D. B. (2013). ScienceDirect Compensatory knowledge signaling in consumer word-of-mouth ir. Journal of Consumer Psychology, 23(4), 434-450. https://doi.org/10.1016/j.jcps.2013.05.002

Park, C. (2004). Efficient or enjoyable? Consumer values of eating-out and fast food restaurant consumption in Korea. International Journal of Hospitality Management, 23(1), 87-94. https://doi.org/10.1016/j.ijhm.2003.08.001

Part, R. C. (2010). 기사 (Article) 와 안내문 (Information) [. Unit 07, 1-5.

Permana, D. (2017). Toward the Best Model of Strategy Implementation in Indonesian Islamic Banking from the Lens of Strategic Clarity. European Research Studies Journal, XX(4B), 315

Pramatatya, V., Najib, M., \& Nurrochmat, D. R. (2004). Pengaruh Atmosfer Kedai Kopi Terhadap Emosi Dan Keputusan Pembelian Ulang. Jurnal Manajemen Dan Agribisnis, 12(2), 126-136. https://doi.org/10.17358/jma.12.2.126

Qing, P., Lobo, A., \& Chongguang, L. (2012). The impact of lifestyle and ethnocentrism on consumers' purchase intentions of fresh fruit in China. Journal of Consumer Marketing, 29(1), 43-51. https://doi.org/10.1108/07363761211193037

Ramdini D.H, H. H. . (2020). The Influence of Knowledge management. Dinasti International 
Journal of Management Science, 1(2), 191-203. https://doi.org/10.31933/DIJMS

Rekarti, E., Doktoralina, A.B., \& Saluy, A.B. (2018). Development model of marketing capabilities and export performance of smes: a proposed study. European Journal of Business and Management, 10(22), 107-114

Robinson, O. C. (2014). Sampling in Interview-Based Qualitative Research: A Theoretical and Practical Guide. Qualitative Research in Psychology, 11(1), 25-41. https://doi.org/10.1080/14780887.2013.801543

Robson, K., Plangger, K., \& Campbell, C. (n.d.). Objective and Subjective Wine Knowledge: Evidence from an Online Study. 2008.

Roseman, M. G., Joung, H., Choi, E. C., \& Kim, H. (2017). The effects of restaurant nutrition menu labelling on college students 'healthy eating behaviours. 2000(11), 1-8. https://doi.org/10.1017/S1368980016002871

Shields, P.M., \& Rangarajan, N. (2013). A playbook for research methods: integrating conceptual frameworks and project management. Stillwater, OK: New Forums Press. https://en.wikipedia.org/wiki/Descriptive_research

Shuttleworth, M. (2008). Quantitative Research Design. Explorable.com: https://explorable.com/quantitative-research-design

Shim, M., \& You, M. (2015). Cognitive and affective risk perceptions toward food safety outbreaks: mediating the relation between news use and food consumption intention. Asian Journal of Communication, 25(1), 48-64. https://doi.org/10.1080/01292986.2014.989242

Tasurru, H. H., \& Salehudin, I. (2014). Global Brands and Consumer Ethnocentrism of Youth Soft Drink Consumers in Greater Jakarta, Indonesia. ASEAN Marketing Journal, 6(2), 77-88. https://doi.org/10.21002/amj.v6i2.4212

Topaloğlu, C. (2012). Consumer Motivation and Concern Factors for Online Shopping in Turkey. Asian Academy of Management Journal, 17(2), 1-19.

Toto Handiman, U., \& Ali, H. (2019). The Influence of Brand Knowledge and Brand Relationship On Purchase Decision Through Brand Attachment. International Journal of Business Marketing and Management (IJBMM), 4(1), 49-56. www.ijbmm.com

Vigar-Ellis, D., Pitt, L., \& Caruana, A. (2015). Knowledge effects on the exploratory acquisition of wine. International Journal of Wine Business Research, 27(2), 84-102. https://doi.org/10.1108/IJWBR-09-2014-0038

Wang, E. S. T. (2015). Effect of food service-brand equity on consumer-perceived food value, physical risk, and brand preference. British Food Journal, 117(2), 553-564. https://doi.org/10.1108/BFJ-09-2013-0260

Wang, E. S. T., \& Yu, J. R. (2016). Effect of product attribute beliefs of ready-to-drink coffee beverages on consumer-perceived value and repurchase intention. British Food Journal, 118(12), 2963-2980. https://doi.org/10.1108/BFJ-03-2016-0128

Wulandari, R. (2012). Dimensi-Dimensi Persepsi Risiko Keseluruhan Konsumen. Jurnal Riset Manajemen Dan Bisnis, 7(2), 115-124.

Yeung, R., Yee, W., \& Morris, J. (2010). The effects of risk-reducing strategies on consumer perceived risk and on purchase likelihood: A modelling approach. British Food Journal, 112(3), 306-322. https://doi.org/10.1108/00070701011029174

Yoo, J.-J., \& Kim, H.-Y. (2012). Perceived Risk of Sunless Tanning Product Use and Its Relationship to Body Satisfaction. International Journal of Marketing Studies, 4(4), 13-21. 
https://doi.org/10.5539/ijms.v4n4p13 